\title{
Validation of ERP Implementation Framework for Private Institution of Higher Learning (PIHL) in Malaysia: A Delphi Technique
}

\author{
Raja Mohd Tariqi Raja Lope Ahmad ${ }^{1}$, Mohd Fahmi Mohamad Amran ${ }^{1}$, Zalinda Othman², \\ Muriati Mukhtar ${ }^{2}$ \\ Faculty of Computer Science and Information Technology, \\ Universiti Selangor, Malaysia \\ 2Faculty of Information Science and Technology \\ Universiti Kebangsaan Malaysia, Malaysia
}

\begin{abstract}
Enterprise resource planning (ERP) system implementations hold great potential for institutions of higher learning (IHL) despite of many literatures have shown that there are many failures during the implementation process. A further understanding of the proposed implementation framework of ERP system for private IHL in Malaysian environment that leads to the successful of the ERP system implementation would be beneficial. In this study, researcher has implemented the validation on the developed implementation framework and the result on the validation is based on the approval from all eight experts after implementing the two rounds of Delphi technique.
\end{abstract}

\section{General Terms}

Enterprise Resource Planning (ERP)

\section{Keywords}

Delphi Technique, Framework and Institution of higher learning

\section{INTRODUCTION}

The establishment of the framework for the implementation of ERP system in private institution of higher learning (PIHL) environment is a complex study. Based on the study conducted on the literature review and field studies, the researchers has found that the function of the role played by institutions of higher learning (IHL) is very broad and different from other organizations. Therefore, the suggested framework here is based on the hybrid framework which was developed by previous scholars (through books, case studies and published ERP research articles which are being reviewed for the implementation), the constraints mentioned for the IHL as a unique environment and our own case study on the ERP system implementation that has been developed base on the PIHL in Malaysia environment, research output on the perception and barriers for the ERP system implementation throughout the fifty (50) private universities in Malaysia. Furthermore, the framework also includes the first author provided firsthand information based on his experiences as a key member on ERP system implementation over a period of five (5) years. All the above information has been gathered which then being systematically unified in order to identify phases, critical success factors (CSF), deliverables and responsibilities. This framework has four stages, which comprise of project initiation, project execution, realization and operation and maintenance in which for each phase or stage will have a combination of CSF, deliverables and responsibilities.

This study will describe the validation result on the proposed framework. The validation study is to obtain feedback on the draft proposal of the framework and get the recommended improvements to rectify the weaknesses of the proposed framework. With the results of this study, researchers will examine whether the implementation of the framework is understandable, appropriate and accurate.

\section{LITERATURE REVIEW}

A Delphi technique research method is a tool developed and based on the qualitative study in which it will use the opinions from the expert that focus on the areas to be reviewed or developed by the research objectives. [1] stated that the Delphi technique may be deemed as a method for structuring group communication process so that it becomes more effective. On the whole, dealing with complex problems, as indicated [2], the objective of most Delphi technique is the exploration of ideas that are creative and can be trusted to issue the appropriate information in making decision.

Delphi method has been praised as a reliable method as well as a creative tool for exploring new ideas to recognize the results of human values [2]. [3] also added that the Delphi technique is a famous method and [4] also said that Delphi technique is a good method for qualitative research. In addition, using Delphi method has proven its value in diverse industries which include technology, education, and other disciplines [5], While [6] has added that Delphi has a rich history and has been used since time immemorial. [6] set the original features of the Delphi method in order to obtain reliable data on the approval of the opinion, the use of the clear and precise questionnaire, the ability to control the feedback received and extension of [7] which stated that the participation of members of the expert panel made anonymously important feature that separates the Delphi method from other qualitative research methods.

Therefore, the main characteristics of the Delphi method, such as asynchronous method and nature anonymous allow this panel of experts to participate in the study group and communication processes within their schedules and availability. Next, the anonymous nature of the Delphi method has also allowed the identification and evaluation of ideas and at the same time to remove the tendency of partisanship in the process of interaction between these groups [1]. Delphi method is a valuable tool to use when there is a problem that 
requires subjective judgments to reach a collective decision and the basis when there is no right answer then there is a problem [8]. [8] also stated that the Delphi method is very valuable when it is difficult to bring together members of the panel because of time constraints and cost.

ERP industry is famous in the early 1990s and many testimonies of the experts have stated that it is an important matter to be explored. Many researchers are exploring the ERP industry has been using the Delphi method as the primary mechanism for collecting their data [9]. [10] has used the Delphi method to identify the risks of software projects by using the panel of international experts from the United States, Finland and Hong Kong. Another reason for [10] too choose the method was that it is believed to have views of the divergent from the expert panels rather than the opinions collected from a single expert.

[11] has chosen Delphi as the research method to determine the perceptions of executives of selected institutions of higher learning on best practices in the ERP implementation. The researchers chose to select the executives at these institutions of higher learning as the expert panel for the Delphi method, because they are able to measure the impact of best practices during implementation in their respective institutions. [12] had also using the Delphi and interview information systems management community has been directly involved in the ERP implementation in their organizations. [12] also stated that the Delphi method is being used to get a broader view on the issues that arise during the ERP implementation from individuals who have close relationship regarding to the ERP implementation in their organizations.

\section{SAMPLING DEVELOPMENT}

Like any other research, selection and sampling for population are important for research results. After completing the literature research on Delphi technique, the following information has been taken into consideration for this method.

\subsection{Delphi Authentication and Researcher Approach}

Delphi is the relevant research method to know technical perspective, organizational perspective and personal perspective [13]. An individual can give different opinion compared to the group perspective in decision making, [14] and [4] have stated that the Delphi technique can be implemented in long-term scale and can also be experimented by scientific ways.

Based on the studies executed by [15], they have listed information system studies that had been using the Delphi method. That study is like forecasting and identification of issues and study for framework or conceptual development. Most of the Delphi method efforts was for genuine forecasting which including short-term and long-term predictions. Follow-up studies have demonstrated the validity and accuracy for long-term Delphi technique. While most prediction study have used Delphi by [16] emphasizing that this differences of views can build one set of alternative scenarios for the future.

Other than that, the framework development or concept development research is another method that always used the Delphi method [15]. This research designs usually involved with processes, such as identification / description of the concept followed by classification / taxonomy development. Example of researches using the Delphi method for framework development, such as mentioned by [17] who developed framework in the fields of information system, [18] who developed descriptive framework for knowledge management and [19] who developed a taxonomy concept on action design of organization in information technology.

In this research, researcher wants to complete the answer form for the expert panel by asking them to provide a justification for each answer, justification and information sharing with the panel members. Researcher also hopes to fully utilize the panel member's expertise. Researcher has also planning to limit partiality on improving Delphi method's validity by conducting a pilot test on the questionnaire. It is expected can increase the clarity on the research tools and at the same time it can also limit the issues that is inclined towards biased happen [20].

\subsection{Panel Member's Selection}

An experienced panelist can provide better answer and it is also will increase study credibility [21]. The panelist member must have experience that is reasonable on the study that is being carried out [7],[22] and criteria for panel member selection usually prepared by researcher [8]. In this research, the researcher will use simple random sampling method to choose expert panelist and based on their availability [23] [23] has also said that probability sampling is useful when conducting exploratory research.

Non probability sampling for the study is necessary for several reasons. Random panel member's selection is not a guarantee for levels of expertise that they own or their readiness to participate in a few round of research exercise [23]. However, matter of the first magnitude once that always thought by researchers is access to the experts that prepare and committed to engage actively in the research. As such researcher first need to implement research on experts that keen to join and this must be updated closely so that it will not stunt the research process [24]. Based on that information, panel members chosen from that method must have at least three years of experiences on ERP system implementation's and have also involved in at least one full implementation ERP project.

[25] states that individuals that have knowledge in some field should be considered as expert panelist and Scheele also states that expert panelist must be comprised of various experiences, while other researchers state that the experience diversity was not necessary, such as by [24] and [1]. They have stated that main reason for Delphi technique is to elicit opinion from experts that have diversity of experiences so that the most critical component in expert panel selection was the levels of experiences compared that to the diversity of the expert panel members. Based on the above arguments, the target of the researcher is to raise homogeneous panel group and their individual experiences in implementing the research while also ensure that they are knowledgeable and committed to join this research.

\subsection{Panel Members Size}

There are many literature studies which states on the suitable panel size for Delphi method. [8] has disputed that the panel size should equally large with the investment of the research and time constraint. [8] has also stated that expert panelist should be between 7-10 people and recommending the member between 13 - 15 is the optimum size. While [6] on the other hand has thought that the panelist size can be as many as 15-35 people, and as for [10] has the opinion that it important to form panelist that is sufficiently to permit variety of opinions. Besides that, [26] have stated that a group that 
homogeneous of between 15-30 members are real enough, while [27] believed that panelist size should have three kinds namely 19,13 and 9 to gauge computer software project in United States, Finland and Hong Kong. As for the research that conducted by [28] has stated that 22 participants must be involved in such study.

As for study, the researcher has proposed a total size for expert panel members as many as 8 - 10 people that consisting of those who have the homogeneous expertise specifically in ERP system implementation. The number of panelist of between $8-10$ people is appropriate due to reason of lack of panel that has experienced in ERP system implementation in Malaysian IHL environment.

\section{RESEARCH ANALYSIS}

Analysis of this study can be divided into several sections; a) pilot study; b) first round review process; c) second round review process and d) summary.

\subsection{Pilot Study}

The pilot study involves three participants with two of them do having experiences in developing information system and ERP system implementation while the other one is an academician. The participants take about three weeks to complete the revision process of the questionnaire. On conclusion, they agreed with the questionnaire and only minor correction involved.

This pilot study process started with the researcher meeting with each participant to further explain the purpose of the research. This process has taken about a week for the researcher to get the feedback from the participants. After the researcher received feedback from the participants of the pilot study, all the comments and suggestions are being incorporated into a new questionnaire. Later, the questionnaire was sent directly to the panel of experts who have been chosen by the researcher.

\subsection{First Round Review Process}

The questionnaire was sent to the 10 experts. It was sent in two ways, through e-mail and direct hand delivery to the involved expert panels. After a period of five (5) weeks has passed, only 8 experts returned their answers to the researchers which is sufficient as disclosed in literature review that 7 to 10 number of expert members good enough for the implementation of the Delphi technique. However, to obtain the desired number of respondents, the researchers conducted a reminder by e-mail, phone calls and sending text message (SMSes). It is constantly being done in order to get a higher response rate to the questionnaire. Demographic data, such as position held, experience in information technology and the experience in the ERP system implementation in details are as follows (Table 1 to Table 3 ):

Table 1. Expert panel position

\begin{tabular}{|c|c|}
\hline Position & Number \\
\hline IT Director & 1 \\
\hline Chief Executive Officer & 2 \\
\hline Project Manager & 3 \\
\hline Senior Executive & 2 \\
\hline
\end{tabular}

Table 2. Expert panel experience in Information Technology

\begin{tabular}{|c|c|}
\hline IT Experience & Number \\
\hline 10 years -15 years & 6 \\
\hline More than 20 years & 2 \\
\hline
\end{tabular}

Table 3. Expert panel experience in ERP implementation

\begin{tabular}{|c|c|}
\hline ERP Experience & Number \\
\hline 1 years - 2 years & 2 \\
\hline 3 years - 4 years & 2 \\
\hline More than 5 years & 4 \\
\hline
\end{tabular}

While next questionnaire component were as follows, panel members are requested to add up to 11 more CSFs (if any), then panel members were being requested to select up to 10 CSFs which involved in the campus ERP system implementation with the statement to support that selection. After that they are also required to choose which $\operatorname{CSF}(\mathrm{s})$ involved for every phase with statement to support that selection. Finally they were asked to respond and to give any comment on all the deliverables and responsibilities for every phase together with the statement to support their given feedbacks. The critical success factor (CSF) questions for the campus ERP system implementation can be found in question 5 and question 6. In question 5, researcher has listed all the 9 CSFs that was nominated (as shown below) and all the panel members are required to recommend additional CSFs that can be involved based on their experiences (if any).

1. Coordinating resources;

2. Stimulating and facilitating organization among employees and others;.

3. Integration activities;

4. Self-service environment;

5. Developing skill and knowledge;

6. Project management;

7. BPR and system customization;

8. Communication;

9. Quality Assurance (QA)

Based on that survey, all members were being requested to add more CSFs based on their experiences and 13 additional CSFs as feedbacks for the campus ERP system implementation to be taken into consideration (as shown below).

1. Top management commitment

2. Change management and communications

3. Data cleansing and conversion

4. Business process reengineering, practices and control

5. Integration testing and simulation

6. Dedicated team with excellent teamwork

7. Right proven solution (Product) 

8. User training and education
9. Change request management
10. Risk management
11. Business process
12. Post-performance measurement
13. Management review

Next in question 6, all panel members were requested to select up to 10 CSFs which involved in that campus ERP system implementation and consequently, the support statements by the panels on the CSF selection. The researcher concluded that the analysis results are to be based on the number of frequencies for each CSF given. Below are the results based on the top ten of the given listed CSF.

\section{Table 4. List of the selected CSF}

\begin{tabular}{|c|c|c|c|}
\hline No & CSF & Total & Frequency \\
\hline 1 & $\begin{array}{l}\text { Coordinating resources } \\
\text { (Includes: Top management } \\
\text { commitment/ project } \\
\text { champion/ change } \\
\text { management). }\end{array}$ & 8 & $100 \%$ \\
\hline 2 & $\begin{array}{l}\text { Right proven solution } \\
\text { (product) / self-service } \\
\text { environment }\end{array}$ & 2 & $25 \%$ \\
\hline 3 & Project management & 8 & $100 \%$ \\
\hline 4 & $\begin{array}{l}\text { Business process } \\
\text { reengineering, practices and } \\
\text { control }\end{array}$ & 7 & $87.5 \%$ \\
\hline 5 & Communication & 8 & $100 \%$ \\
\hline 6 & Quality Assurance & 8 & $100 \%$ \\
\hline 7 & $\begin{array}{l}\text { Developing skill and training } \\
\text { knowledge }\end{array}$ & 8 & $100 \%$ \\
\hline 8 & $\begin{array}{l}\text { Data cleansing and } \\
\text { conversion }\end{array}$ & 2 & $25 \%$ \\
\hline 9 & Integration activities & 8 & $100 \%$ \\
\hline 10 & 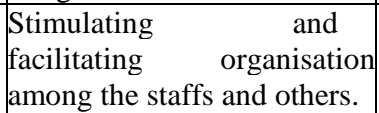 & 5 & $62.5 \%$ \\
\hline
\end{tabular}

Note: Frequency - representing the frequency of CSF selected by the panel members

Based on the frequency that are listed in Table 4, all eight panelists (100\%) think that highest management involvement, project management, quality assurance plan, importance of training and integration activity are the important CSFs to be implemented to ensure the campus ERP system implementation can be successfully implemented. Next highest CSFs frequency selected are (87.5\%) for reengineering process, system update and control and lastly $(62.5 \%)$ as efforts to stimulate and facilitating organisation between the employees and others to be implemented. These are the CSFs that are important to be implemented in order to make sure the ERP system implementation a success in the PIHL. As for other CSFs, such as right proven solution (product) / self-service environment and data cleansing \& conversion $(25 \%)$, there are only 2 panel members selected for each CSF respectively. Due to the frequency support for those CSFs is less than $50 \%$, researcher decided to reject those CSFs. Therefore, the CSFs that are most important to be applied are the being listed below;
1. Coordinating resources (Includes: Top management commitment/ project champion/ change management).

2. Project management

3. Business process reengineering, practices and control

4. Communication

5. Quality Assurance

6. Developing skill and knowledge training

7. Integration activities

8. Stimulating and facilitating organisation among employees and others.

Next, the analysis continues with all the panel members required to map the selected CSFs into every phase and justification that being administered based on that selection. Results of the analysis are formulated as indicated in Table 5.

Table 5. List of the selected CSF

\begin{tabular}{|l|l|}
\hline Phase 1 & $\begin{array}{l}\text { Coordinating resources } \\
\text { Communication } \\
\text { Quality assurance }\end{array}$ \\
\hline Phase 2 & $\begin{array}{l}\text { Coordinating resources } \\
\text { Project management } \\
\text { Communication } \\
\text { Quality assurance } \\
\text { Developing skill and knowledge / training }\end{array}$ \\
\hline Phase 3 & $\begin{array}{l}\text { Coordination resources } \\
\text { Project management } \\
\text { Business Process reengineering, practices \& } \\
\text { control } \\
\text { Communication } \\
\text { Quality Assurance } \\
\text { Developing skill and knowledge / training } \\
\text { Integration activities } \\
\text { Stimulating and facilitating organisation among } \\
\text { employees and others }\end{array}$ \\
\hline Phase 4 & $\begin{array}{l}\text { Coordination resources } \\
\text { Quality Assurance } \\
\text { Communication } \\
\text { Developing skill and knowledge / training }\end{array}$ \\
\hline
\end{tabular}

All panel members had agreed on the ERP system implementation framework that has been decided. Most of the panel members have given their recommendations that all phases must involve the top management, information about who is responsible for the implementation for every phase shown in Table 6:

Table 6 ERP System Implementation Framework Responsibility

\begin{tabular}{|c|l|c|c|}
\hline Phase & \multicolumn{1}{|c|}{ Responsible } & Yes / No & Suggestion \\
\hline 1 & $\begin{array}{l}\text { IT Division, Faculty } \\
\text { members, } \\
\text { Department, Academic } \\
\text { Affairs Student } \\
\text { Finance Department, } \\
\text { Human Resource and } \\
\text { Hertment, } \\
\text { Administration } \\
\text { Department -Users - }\end{array}$ & $\begin{array}{l}\text { Top } \\
\text { Management }\end{array}$ & \\
\hline
\end{tabular}




\begin{tabular}{|c|l|c|c|}
\hline 2 & $\begin{array}{l}\text { User, Consultant and } \\
\text { Vendor }\end{array}$ & Yes & $\begin{array}{c}\text { Top } \\
\text { Management }\end{array}$ \\
\hline 3 & $\begin{array}{l}\text { User, Consultant and } \\
\text { Vendor }\end{array}$ & Yes & $\begin{array}{c}\text { Top } \\
\text { Management }\end{array}$ \\
\hline 4 & $\begin{array}{l}\text { User, Consultant and } \\
\text { Vendor }\end{array}$ & Yes & $\begin{array}{c}\text { Top } \\
\text { Management }\end{array}$ \\
\hline
\end{tabular}

\subsection{Second Round Review Process}

The second round review process is being implemented after the researcher has completed the comprehensive analysis process on all the feedbacks obtained from all the panel members. Based on the responses received, the researcher has identified things that would require the approval from all the panel members. Here are what was agreed upon by all the panel members about on the deliverables and responsibilities to every phase as outlined in Table 6 and Table 7 .

Table 7: ERP system Implementation Framework Deliverables

Phase 1: Project Initiation (Pre - Implementation)

\begin{tabular}{|l|l|}
\hline No & \multicolumn{1}{|c|}{ Deliverables } \\
\hline A & Institution environment analysis \\
& A.1: Internal analysis \\
& A.2: External analysis \\
& A.3: Current ICT analysis \\
\hline B & Selection Process \\
& B.1:ERP software selection \\
& B.2:Vendor \& Consultant selection \\
& B.3: ICT Infrastructure \\
& B.4:Feasibility study \\
& B.5: Contract seal \\
\hline
\end{tabular}

Phase 2: Project Preparation (During implementation)

\begin{tabular}{|l|l|}
\hline No & \multicolumn{1}{|c|}{ Deliverables } \\
\hline A & A. 1: Project scope and objective \\
& A.2: Project scheduling \\
& A.3: Project organisation chart \\
& A.4: Policy and procedure \\
\hline
\end{tabular}

\begin{tabular}{|l|l|} 
Phase 3: Realization (During Implementation) \\
\hline No & \multicolumn{1}{|c|}{ Deliverables } \\
\hline A & $\begin{array}{l}\text { A. 1: Project scope and objective } \\
\text { A.2: Project scheduling } \\
\\
\\
\text { A.3: Project organisation chart } \\
\text { A.4: Policy and procedure }\end{array}$ \\
\hline
\end{tabular}

Phase 4: Maintenance and Operation (Post-Implementation)
\begin{tabular}{|c|l|}
\hline No & \multicolumn{1}{|c|}{ Deliverables } \\
\hline A & $\begin{array}{l}\text { A. 1: Project scope and objective } \\
\text { A.2: Project scheduling }\end{array}$ \\
& $\begin{array}{l}\text { A.3: Project organisation chart } \\
\text { A.4: Policy and procedure }\end{array}$ \\
\hline
\end{tabular}

Analysis of the result obtained from first round review process has shown that the second confirmation needs to be implemented in order to get approval from the involved panel members. The approval is on all the 8 CSFs and which phase those CSFs are involved. Based on the result of the analysis, the researcher has developed the questionnaire for the second phase review process which focus on the agreement for the selected CSFs and which phase the CSFs will be involved. Furthermore, the questionnaire given to all panel members will collect the feedback and responses from them. This round two implementation process will take 2 weeks from delivery date of the questionnaire. Result from all panel members are positive, in which all of them are agreeable to the $8 \mathrm{CSFs}$ given. Besides that, the result for which the CSFs involved at every phase has also got positive feedback and agreement from all the panel members.

\section{SUMMARY}

In this study, researcher has implemented validation on the development of ERP system implementation framework and result on the validation is based on the approval from all 8 experts after completing the two rounds of Delphi technique. In this study, researcher has obtained approval on the 8 CSFs for ERP system implementation in PIHL. The study has also mapped the involved CSFs accordingly to every phase (refer to Table 5) and deliverables and responsibilities ERP system implementation framework (refer to Table 6 and Table 7). Future research will be focused on other possible case study development which related with the proposed ERP Implementation Framework.

\section{REFERENCES}

[1] Turoff, M. \& Hiltz, S., Computer Based Delphi Processes,http://wwww.eies.njit.edu/ turoff/Papers/delph i3.htm, downloaded: April, 25th 2014.

[2] Gunaydin, H., The Delphi method: Definition and Historical Background. http://web.iyte.edu.tr/ muratgunaydin/delphi.htm, downloaded: May, 4th 2014.

[3] Jones, T.E., Options For The Future: A Comparative Analysis of Policy-Oriented Forecasts, (Praeger) New York, 1980.

[4] Woudenberg, F., "An evaluation of Delphi". Technological Forecasting and Social Change, Vol. 40, no. 2, pp. 131-150, 1991.

[5] Cornish, E., The Study of the Future: An Introduction to the Art and Science of Understanding and Shaping Tomorrow's World, (Transaction Publishers), Washington, D.C., 1977.

[6] Gordon, T., The Delphi Method. Futures Research Methodology From The AC/UNU Millennium Project. http://wwww.futurovenezuela.org/-curso/5-delphi.pdf, downloaded: May, 11th 2014.

[7] Lang, T., An Overview of Four Futures Methodologies Manoa Journal of Fried and Half-Fried Ideas, http ://www. soc. hamaiii. edu/ future/j 7/LAN G. html, downloaded: June, 10th 2014.

[8] Mitchell, V., "The Delphi Technique: An Exposition and Application. Technology Analysis \& Strategic Management”, Vol. 3, no. 4, pp. 333-358, 1991.

[9] Fowles, J., Handbook of Futures Research, (Greenwood Publishing Group), Connecticut, 1978.

[10] Schmidt, R., Lyytinen, K., Keil, M. \& Cule, P., "Identifying Software Project Risks: An International Delphi Study", Journal of Management Information Systems, Vol. 17, no. 4, pp. 5-36, 2001. 
[11] Frantz, P.S., Perceptions of Selected Administrators Regarding Enterprise Resource Planning Software Implementation Best Practices, and The Relationship Between These Perceptions and Selected Variables, Tesis Ph.D., University of Southern Mississippi, 2001.

[12] Chang, S.I. \& Gable, G.G., "A Comparative Analysis of Major ERP lifecycle Implementation, Management and Support Issues in Queensland Government", Journal of Global Information Management, Vol. 10. No. 3, pp.36ᄀ54, 2002.

[13] Cuhls, K., "From Forecasting to Foresight Processes New Participative Foresight Activities in Germany", Journal of Forecasting, Vol.22, no. 2-3,pp.93-111,2003.

[14] Linstone, Harold A. \& Ian I. Mitroff, The challenge of the 21st century: Managing technology and ourselves in a shrinking world, (State University of New York Press), New York, 1994

[15] Okoli, C. \& Pawlowski, S.D., "The Delphi Method As a Research Tool: An Example, Design Considerations and Applications", Information \& Management, Vol. 42, no. 2004, pp. 15-29, 2004.

[16] Kendall, J.E., Kendall, K.E., Smithson, S. \& Angell, I.O., "SEER: A Divergent Methodology Applied To Forecasting The Futureroles of The Systems Analyst", Human Systems Management, Vol.11, no. 3, pp.123ᄀ135, 1992.

[17] Bacon, C.J. and Fitzgerald, B., "A systemic framework for the field of information systems", ACM Sigmis Database, Vol.32, no.2, pp.46-67, 2001.

[18] Holsapple, P. \& Joshi, K., "Knowledge Manipulation Activities: Results of A Delphi Study. Information \& Management", Vol. 39, no. 6, pp. 477-490, 2002.

[19] Narayanan, V.K. \& Fahey, L, "The Micro-politics of Strategy Fomulation. Academy of Management", Review, Vol. 7, no. 1982, pp. 25-34, 1982.
[20] Carson, W.A., Successful Implementation of Enterprise Resource Planning Software: A Delphi Study, Tesis Ph.D, Capella University, 2005.

[21] Welty, G., "Problems of Selecting Experts For Delphi Exercices", Academy of Management Journal, Vol. 15, no. 1, p. 121-124, 1972.

[22] Rowe et al. 1991 Rowe, G., Wright, G. and Bolger, F., "Delphi: a re-evaluation of research and theory", Technological Forecasting Social Change, Vol. 39, pp. 235-251, 1991.

[23] Herek, G.M., A Brief Introduction To Sampling. http://www.psychology.ucdavis.edu/rainbow/html/fact_s ample [3 November 2010], 2004.

[24] Voctech, Using Delphi Technique in Assessing Needs For VTET, http://www.voctech.org.bn, downloaded: June, 21th 2014.

[25] Scheele, D. S., Reality construction as a product of Delphi interaction, In H. A. Linstone \& M. Turoff (Eds.), The Delphi method: Techniques and applications (pp.37ᄀ71). Reading, (Addison-Wesley Publishing Company), MA, 1975.

[26] Dunham, R., Organizational Behavior: The Delphi Technique, http:// instruction.bus.wisc.edu/obdemo/readings/delphi.html, downloaded: July, 10th 2014.

[27] Keil, M., Cule, P.E., Lyytinen, K. \& Schmidt, R.C., "A Framework For Identifying Software Project Risk", Communications of the ACM, Vol. 41, no. 11, pp. 76-83, 1998.

[28] Warters, W.C., "Graduate Studies In Dispute Resolution: A Delphi Study of The Field's Present and Future", The online Journal of Peace and Conflict Resolution, Vol. 2, no. 2, pp. 1-12, 1999. 